\title{
Erratum
}

40. Vijayaraman P, Bordachar P, Ellenbogen KA (2017) The continued search for physiological pacing. J Am Coll Cardiol 69:3099-3114

41. Vijayaraman P, Dandamudi G, Zanon F et al (2017) Permanent His bundle pacing (HBP): Recommendations from a multi-center HBP collaborative working group for standardization of definitions, implant measurements and follow-up. Heart Rhythm Epub Ahead Print Oct 28. https:// doi.org/10.1016/j.hrthm.2017.10.039

42. Vijayaraman $P$, Naperkowski $A$, Ellenbogen KA et al (2015) Electrophysiologic insights into site of atrioventricular block. JACC: Clin Electrophysiol $1: 571-581$
Herzschr Elektrophys 2018 · 29:121

https://doi.org/10.1007/s00399-017-0552-9

Published online: 2 February 2018

(C) Springer Medizin Verlag GmbH, ein Teil von Springer Nature 2018

CrossMark

Redaktion "Herzschrittmachertherapie und Elektrophysiologie“

Springer Medizin Verlag, Heidelberg, Germany

\section{Correction to: Atrial thrombogenesis in atrial fibrillation}

\section{Results from atrial fibrillation models and AF-patients}

\section{Correction to:}

Herzschr Elektrophys 2017

https://doi.org/10.1007/s00399-017-

0543-x

Please accept the Publisher's apologies for the following mistake:

In the first online version of this contribution the title was incomplete. The correct version reads: „Atrial thrombogenesis in atrial fibrillation. Results from atrial fibrillation models and AF-patients".

The original article was corrected.

\section{Corresponding address}

Redaktion „Herzschrittmachertherapie und Elektrophysiologie"

Springer Medizin Verlag

Heidelberg, Germany 